\title{
Implications of Differences in the Moral Standards of Different Cultures to the Nature of Morality
}

\author{
Mansour Moklif Alanazi, $\mathbf{M D}^{1}$, Mohammed Ratoubi Alanazi, $\mathbf{P h D}^{2}$ \\ ${ }^{1}$ Family and Geriatric Medicine, Pain Management Consultant, Riyadh, Saudi Arabia \\ ${ }^{1}$ Director of Family Medicine in King Fahd Military Medical Complex, Riyadh, Saudi Arabia \\ ${ }^{2}$ Chief of Curriculum Development in Military School of Allied Health Sciences in Saudi National \\ Guard Health Affairs, Riyadh, Saudi Arabia \\ ${ }^{2}$ Assistant Professor in King Saud bin Abdulaiz University for Health Sciences, Riyadh, Saudi Arabia
}

\begin{abstract}
Cultural relativism is based on a facile observation that what is considered to be morally right at one time and place (or in one culture) may or may not be considered to be morally right in another. There are no grounds for the assumption that any culture's morality is superior to another, leaving no basis on which the various moralities of cultures can be judged or compared. A major question that must be asked when considering the use of cultural relativism in the study of morality is, how widely do cultures actually vary. This study showed that cultural relativism can often be twisted in order to preclude moral judgment of acts that are clearly wrong, based on the assertion that these acts are traditional within the culture that they are taking place in. This problem is not just the justification of immoral acts, but the continued assumption of superiority of one culture over another based on the assertion that some cultures cannot change.
\end{abstract}

Key Words: cultural relativism, moral standards, morality, norms

\section{INTRODUCTION}

The position that different cultures have deeply different moral standards, and that these standards are incommensurate and not directly comparable, is a position of cultural relativism (Gensler 2011). The analytical position of cultural relativism is useful in social sciences such as anthropology and sociology, as it allows for the researcher to understand the moral norms and practices of other cultures without ethnocentrism (Ferraro and Andreatta 2009; Ferrante 2012).
However, from a philosophical point of view cultural relativism is problematic because it eliminates any standard by which certain acts may be judged. Furthermore, those that transgress moral boundaries may use cultural relativism mendaciously in an attempt to justify these actions as an expression of traditional culture. Thus, to accept cultural relativism uncritically is to create conditions where it is not possible to question the morality of an act except in the context of one's own (narrowly defined) culture, while erodes the fundamental nature of morality and ethics. Although cultural relativism has its place in analytical assessment, it cannot be allowed to preclude any possibility of ethical analysis or moral judgment.

Cultural relativism is based on a facile observation that what is considered to be morally right at one time and place (or in one culture) may or may not be considered to be morally right in another (Stevens 2008). For example, it is morally permissible in Saudi Arabia to have more than one wife up to four wives, and in Indian it is morally permissible that wives to be burned alive along with their dead husbands on a funeral pyre; however, none of these examples (in Saudi Arabia and/or India) are morally permissible in Australia. Those that take a position of cultural relativism argue that no culture can be deemed to be superior to another (to argue otherwise is ethnocentric) (Stevens 2008). Thus, based on this argument, there are no grounds for the assumption that any culture's morality is superior to another, leaving no basis on which the various moralities of cultures can be judged or compared (Stevens 2008). 
Instead, the only relation that is possible is between another culture and one's personal morality; statements of $\mathrm{X}$ act is wrong must be reduced to $\mathrm{I}$ believe that $X$ act is wrong (Stevens 2008). This eliminates much of the conflict in moral assertions and assumptions; however, it does not provide a basis for discerning a science or philosophy of ethics (Stevens 2008). It also does not prepare the individual for an increasingly globalized world, in which the moralities of different cultures, rather than being strictly contained within a geographical region are constantly in contact and in conflict (Stevens 2008). Thus, one of the major perils of cultural relativism in regard to the nature of morality is that it reduces morality to a personal set of beliefs and constructs, rather than a meaningfully shared set of beliefs.

A major question that must be asked when considering the use of cultural relativism in the study of morality is, how widely do cultures actually vary? Stevens (2008) argues that in actuality, the basic principles of morality do not vary significantly between cultures; instead, it is only the derived expressions of morality (the manners and behavioural norms) that vary greatly. Many universal basic principles, such as prohibitions against lying, killing members of one's own society, and incest, derive from the dual nature of humans as social, yet selfish, creatures (Stevens 2008). These principles serve to hold societies together by prescribing limits to the expression of selfishness of the individual; furthermore, these principles are consistent because the basic rules by which human societies are organized are consistent (Stevens 2008).

There are many cases, even in the extreme, where a seemingly disparate set of norms and practices can be reduced to similar principles. One example is the practice of female infanticide among Eskimo groups (Rachels and Rachels 2010). On its face, this is a morally wrong practice to Western eyes, as infants are to be protected and not killed. However, in the Eskimo context of scarce food supplies, long nursing periods, and the dramatically greater risk to adult males than females, this makes sense; it is an act performed in recognition of the need to provide resources for the existing group (an expression of the social nature of humanity) and the limitations imposed by the environment (Rachels and Rachels 2010). This example shows that in order to understand cultural practices, it is necessary to look below the first level of norms and practices and examine the underlying moral principles that are at work in generating these norms and practices before it is possible to understand how a practice comes about. Thus, the similarity of core values (even in the face of widely varying practices) requires not acceptance of cultural relativism as an analytical position, but instead a deepening of the analysis to get at these core values.

\section{The effects of applying cultural relativism to the nature of morality}

These arguments are not meant to indicate that cultural relativism should have no role in the study of ethics. As Bond (1996) points out, there are important uses for cultural relativism in ethics. In particular, cultural relativism is a means of overcoming psychological egoism, or the assumption that one's own moral standards are the correct or right moral standards (or alternatively the only standards that are moral). Cultural relativism, by its removal of the assumption of universal morality and substitution of the understanding that moral standards vary widely by time and place, allows for the elimination of the self in the assessment of morality and critique (Bond 1996).

However, Bond also notes that this view frequently reduces morality to mere standards of behaviour or manners, which is not truly reflective of underlying norms regarding morality and its practice (Bond 1996). Thus, even though cultural relativism has a use in Bond's (1996), it must not be used to reduce ethical standards to simple behavioural standards, since this once again reduces morality to the level of the individual rather than a shared society. In particular, while this removal of psychological egoism from a position of importance in analysis does mean that a particular injustice of Western academic research the assumption of Western society's superiority over others - is removed; it also removes the ability to critique practices that are by most standards immoral (Rachels and Rachels 2010). One example is the authoritarian practices of the Chinese state, which include brutal repression of political dissent, including armed military action against unarmed civilians; under a cultural relativism viewpoint, there is nothing to say about this practice, which must simply be accepted because it is accepted within Chinese culture (Rachels and Rachels 2010). In addition, of course overlooking the obvious problem (that if this behaviour were actually accepted within Chinese culture there would be no dissent to repress), it also reduces any critique of this regime to that of personal 
disagreement, not a meaningful statement regarding right and wrong. Thus, although cultural relativism is useful in a limited fashion, it must not be used to simply refute the notion of morality as a whole.

There are many other examples that demonstrate the ways in which cultural relativism reduces the understanding and practice of morality. One example is the human rights practices of Iran, including executions, imprisonments, and the repression of women (Afshari, 2011). These practices are routine and justified by the Iranian government under the mantle of traditional cultural practice and religion, which is intended to have the effect of insulating them from outside critique (Afshari 2011). However, Iran is far from the only government that uses claims of tradition and culture to shield itself from critique regarding its actions. For example, the Israeli government makes many of the same claims, including a claim to traditional rights to the land, religious claims, and justice-seeking from prior persecution, to justify its treatment of Palestinians within its borders (Strong 1998). In fact, Strong (1998) identifies the same drivers of these positions of opposing states at work in these two cases. How using cultural relativism in such this conflict to be resolved? The facile resolution offered by Stevens (2008) is of no use in this situation; even if the problem is reframed, as $\mathrm{X}$ believes $\mathrm{Y}$ is wrong and vice versa, there is still the potentially violent disagreement of large and well-armed states to contend with. Thus, cultural relativism has limited use in practical applications of morality and ethics, as it precludes any useful solution.

This is a point reiterated by authors discussing Non Governmental Organizations (NGOs) participation in global civil society, who point out that societies no longer stop at international borders; instead, the position of judgment of a state's actions is now international and global (Clark, Friedman et al. October 1998). Thus, the argument of a sovereign state that its actions are moral because they are appropriate under the norms of that society is no longer valid. Furthermore, the position that some societies must retain norms because they are traditional implies an on-going oriental's viewpoint that underhandedly continues to assert the unchanging and static nature of non-Western societies. Orientaliste thought is at the centre of the colonialist activity, and its core principle is that some societies (Western societies) are superior to others, among other reasons because they have the ability to grow and change (Said 2003). Thus, to assert in the face of international disapprobation of a given cultural practice that it must not be criticized because it is a cultural practice, as both Iran and Israel insist upon, is to remove the power of cultural relativism to eliminate hierarchies of cultures. This use of cultural relativism actually reinstates the position of moral superiority, when its rejection is one of the main uses of the principle in the first place.

This leaves the question of morality and biology. A strict position of moral universalism would imply that morality was in some sense encoded in our genes, and that it was an innate physical or cognitive characteristic of humans. A study suggests that morality and ethics are an expression of culture, not of nature, and that this means that there is no universal nature of morality; thus, we must accept the position of cultural relativism, reducing ethical standards differences to simple disagreements (Nitecki and Nitecki 1993). However, there are other arguments that suggest that morality does have an evolutionary purpose, and that it evolved alongside the evolution of Homo sapiens as a social mammal as a means of improving fitness (Campbell 1998). Under this view, morality plays an important role in ensuring the survival of the group, which is the main aim of sociality among humans (Campbell 1998).

The evolutionary role of morality does not imply that all human cultures will have the same expression of morality, as humans are among the most elastic (or individually adaptable) of all species and various genetic traits are expressed differently depending on environment (Bogin 1999). There is also evidence that the basic structures of human society demand the development of core principles and practices (i.e. morals) even when the environment generates pressures for the evolution of different norms and practice (i.e. manners) (Rachels and Rachels 2010). Thus, it is simplistic to say that cultural relativism must simply be accepted because morality is not biologically determined; in fact, the biological determination of morality is not clearly understood, and it cannot be presumed that the basic principles of morality as an enabler of social organization are not biologically determined.

\section{Conclusion}

This article has elaborated on a number of points regarding cultural relativism. First, it is fundamentally 
destructive to the idea of shared morality because the only determination that can be made from a culturally relativist standpoint is that an act is personally immoral, rather than a statement of comparison of wider culture. Furthermore, it demonstrated that the basis of cultural relativism - that the moral norms and values of cultures vary widely - is often overstated and thus that the use of moral relativism in the analysis of morality is not actually as useful as it may be. Then, this article demonstrated the contrary to cultural relativist arguments that morality is strictly cultural, there are in fact evolutionary reasons for the development of morality and as such it is not possible to strictly exclude the study of morality as a biological trait of humans.

Finally, it showed that cultural relativism can often be twisted in order to preclude moral judgment of acts that are clearly wrong, based on the assertion that these acts are traditional within the culture that they are taking place in. This problem is not just the justification of immoral acts, but the continued assumption of superiority of one culture over another based on the assertion that some cultures cannot change. Although there are some analytical uses of cultural relativism, such as reducing the tendency to psychological egoism, ultimately cultural relativism, if accepted uncritically, precludes the study of morality entirely and reduces this study to an assertion of personal opinions about acts. This substantially reduces, if not eliminates, the strength of morality as a basis of judgment.

\section{REFERENCES}

1. Afshari, R. (2011). Human rights in Iran: The abuse of cultural relativism. Philadelphia, University of Pennsylvania Press.

2. Bogin, B. (1999). Patterns of human growth. Cambridge Cambridge University Press.

3. Bond, E. J. (1996). Ethics and human well-being: An introduction to moral philosophy. Oxford, Blackwell Publishers Ltd.
4. Campbell, B. (1998). Human evolution: An introduction to man's adaptation. New Jersey, Transaction Publishing.

5. Clark, A. M., E. J. Friedman, et al. (October 1998). "The sovereign limits of global civil society: A comparison of NGO participation in UN World Conferences on the Environment, Human Rights, and Women." World Politics 51: 1-35.

6. Ferrante, J. (2012). Sociology: A global perspective. Belmont, WADSWORTH: Cengage Learning.

7. Ferraro, G. and S. Andreatta (2009). Cultural anthropology: An applied perspective. Belmont, WADSWORTH: Cengage Learning.

8. Gensler, H. J. (2011). Ethics: A contemporary introduction. New York, Taylor \& Francis Group.

9. Nitecki, M. H. and D. V. Nitecki, Eds. (1993). Evolutionary ethics. Albany, University of New York Press.

10. Rachels, J. and S. Rachels (2010). The elements of moral philosophy New York, McGraw-Hill.

11. Said, E. W. (2003). Orientalism. New York, Knopf Doubleday Publishing Group.

12. Stevens, D. (2008). "Cultural Relativism and the Nature of Morality." Retrieved 23 March 2012, from

http://www.bioethicseducation.com/attachments/0 27_Cultural\%20Relativism\%20and\%20the $\% 20 \mathrm{Im}$ plication $\% 20$ for $\% 20$ the $\% 20$ Nature $\% 20$ of $\% 20$ Mor ality.pdf.

13. Strong, S. I. (1998). "Law and Religion in Israel and Iran: How the Integration of Secular and Spiritual Laws Affects Human Rights and the Potential for Violence." Michigan Journal of International Law 19: 109-115. 